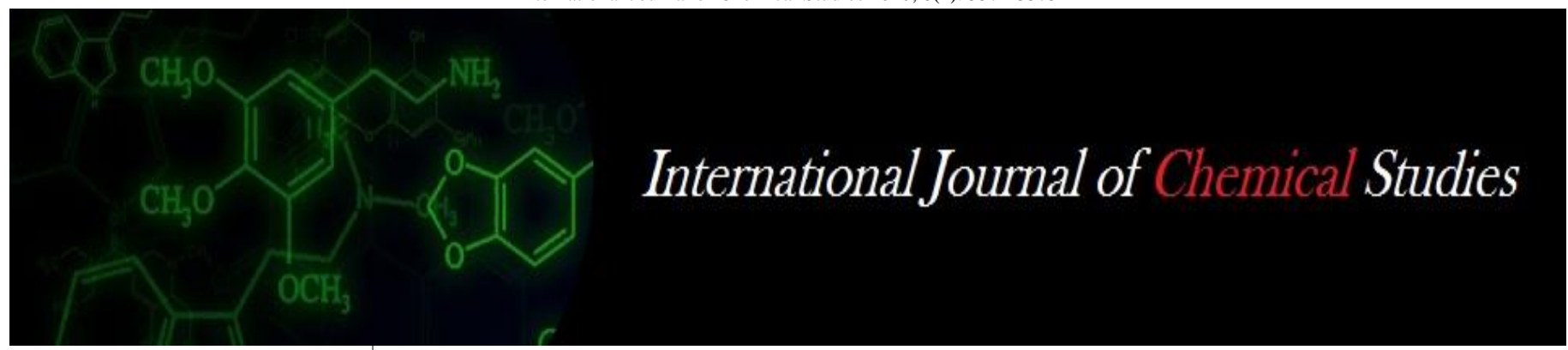

P-ISSN: 2349-8528

E-ISSN: 2321-4902

www.chemijournal.com

IJCS 2020; 8(4): 3571-3575

(C) 2020 IJCS

Received: 13-04-2020

Accepted: 15-05-2020

\section{Kaki Pranaya}

Department of Plant Pathology, College of Agriculture, Professor Jayashankar Telangana State Agricultural University, Rajendranagar, Hyderabad,

Telangana, India

\section{Bharati N Bhat}

Department of Plant Pathology, College of Agriculture, Professor

Jayashankar Telangana State

Agricultural University,

Rajendranagar, Hyderabad,

Telangana, India

\section{G Uma Devi}

Department of Plant Pathology, College of Agriculture, Professor

Jayashankar Telangana State

Agricultural University,

Rajendranagar, Hyderabad,

Telangana, India

\section{S Triveni}

Department of Plant Pathology, College of Agriculture, Professor Jayashankar Telangana State Agricultural University, Rajendranagar, Hyderabad, Telangana, India
Corresponding Author: Kaki Pranaya

Department of Plant Pathology, College of Agriculture, Professor Jayashankar Telangana State Agricultural University,

Rajendranagar, Hyderabad,

Telangana, India

\section{In vitro evaluation of fungicides against Alternaria leaf spot of cotton}

\author{
Kaki Pranaya, Bharati N Bhat, G Uma Devi and S Triveni
}

DOI: https://doi.org/10.22271/chemi.2020.v8.i4as.10203

\begin{abstract}
Cotton (Gossypium hirsutum L.) is the one of the most important commercial crops of the world, which belongs to the family Malvaceae. India is the largest cotton growing country in the world with an area of around 12.35 $\mathrm{M}$ ha followed by United States and China with production of $36.1 \mathrm{M}$ bales and productivity of $524 \mathrm{~kg}$ lint/ha. Cotton crop is known to suffer from number of fungal, bacterial and viral diseases. Cotton is under constant threat of foliar diseases viz., grey mildew, Alternaria leaf spot, Myrothecium leaf spot, bacterial leaf blight, rust etc. Among them, Alternaria leaf spot caused by Alternaria spp. is predominant in causing economic losses to the cotton crop in the country. Evaluation of systemic, non-systemic and combined fungicides under in vitro conditions revealed that the among eight fungicides evaluated against Alternaria macrospora (N2A isolate), Propiconazole, Hexaconazole and Tebuconazole @ 500 and 1000 ppm recorded maximum inhibition with 100 per cent inhibition and no radial growth of mycelium was observed. Pyraclostrobin and Azoxystrobin @ 1000 ppm showed 91.0 and 87.2 per cent inhibition respectively. Carbendazim+Mancozeb (SAAF) @ 1500 ppm and 2000 ppm showed 96.1 and 96.9 per cent inhibition respectively.
\end{abstract}

Keywords: Fungicides, Alternaria, leaf spot, cotton

\section{Introduction}

Cotton is the most essential natural fiber crop in the world for textile produce, accounting for about $50 \%$ of all fibers used in the textile industry. It is grown all over the world in about 80 countries. Cotton is unique among agricultural crops, because it is the main natural fiber crop, and also provides edible oil. It is one of the agro-industrial crops which are produced in both developing and developed countries (Bedane and Arkebe, 2019) ${ }^{[2]}$.

India is the largest cotton growing country in the world with an area of around $12.35 \mathrm{M}$ ha followed by United States and China with production of $36.1 \mathrm{M}$ bales and productivity of 524 $\mathrm{kg}$ lint/ha (Cotton Association of India, 2018-2019). India's share in global cotton exports is around 25 per cent In India, Maharastra (26.63\%), Gujarat (17.96\%), Andhra Pradesh $(13.75 \%)$ and also Madhya Pradesh are the leading cotton producing states. Cotton in India provides direct livelihood to 6 million farmers and about 40-50 million people are employed in cotton trade and its processing (Chitte et al., 2019) ${ }^{[4]}$.

The word "cotton" is derived from Arabic word (qutn or qutun). This was the usual word for cotton in medieval Arabic. Cotton (Gossypium spp.) belongs to the botanical family Malvaceae. Cotton is referred to as "King of Fibres" and also known as "White Gold" (Prasad et al., 2018) ${ }^{[8]}$.

There are four cultivated species of cotton viz., Gossypium arboreum, G. herbaceum, G. hirsutum and $G$. barbadense. The first two species are diploid $(2 \mathrm{n}=26)$ and are native to old world. The last two species are tetraploid $(2 \mathrm{n}=52)$. G. hirsutum is the predominant species which alone contributes about 90 per cent to the global production. Perhaps, India is the only country in the world where all the four cultivated species are grown on commercial scale (Chitte et al., 2019) ${ }^{[4]}$.

The various species of cotton grown as agricultural crops are native to subtropical parts of the world. Cotton can be found as perennial tree like plants in tropical climate but is normally cultivated as a shrubby annual in temperate climates.

Cotton is a heat loving crop. During germination it requires $32-34{ }^{\circ} \mathrm{C}$ and $25-27{ }^{\circ} \mathrm{C}$ during the vegetative stage. Average temperature of $21-22^{\circ} \mathrm{C}$ is required for the crop (Sangameshwari et al., 2019) ${ }^{[10]}$. It is grown between latitudes $30^{\circ} \mathrm{N}$ and $30^{\circ} \mathrm{S}$. 


\section{Materials and Methods}

Selected fungicides were evaluated to study the effect of fungicides against Alternaria sp. under in vitro conditions by employing poisoned food technique (Nene and Thapliyal, 1993). Ten $\mathrm{ml}$ of stock solution of 10 per cent concentration is prepared in sterile distilled water. Twenty $\mathrm{ml}$ of poisoned medium is poured into sterilized Petri plates under aseptic conditions in the laminar air flow chamber and allowed to solidify. These plates were inoculated with $5 \mathrm{~mm}$ diameter disc cut from actively growing periphery regions of Alternaria sp. culture and incubated at $28 \pm 1{ }^{\circ} \mathrm{C}$. PDA plates containing non poisoned food medium and inoculated with Alternaria sp. serves as control. Radial growth of pathogen and per cent inhibition is calculated by using the formula.

$$
I=\frac{\mathrm{C}-\mathrm{T}}{\mathrm{C}} \times 100
$$

Where, $\mathrm{I}=$ Per cent inhibition over control

$\mathrm{C}=$ Radial growth of pathogen in control $(\mathrm{mm})$

$\mathrm{T}=$ Radial growth of pathogen in treatment $(\mathrm{mm})$

List of fungicides evaluated against Alternaria sp:

\begin{tabular}{|c|c|c|c|}
\hline Treatment & Chemical name & Trade name & Rate of concentration \\
\hline T1 & Hexaconazole & Contaf & $500 \mathrm{ppm}, 1000 \mathrm{ppm}$ \\
\hline T2 & Tebuconazole & Folicur & $500 \mathrm{ppm}, 1000 \mathrm{ppm}$ \\
\hline T3 & Propiconazole & Tilt & $500 \mathrm{ppm}, 1000 \mathrm{ppm}$ \\
\hline T4 & Pyraclostrobin & Headline & $500 \mathrm{ppm}, 1000 \mathrm{ppm}$ \\
\hline T5 & Azoxystrobin & Amistar & $500 \mathrm{ppm}, 1000 \mathrm{ppm}$ \\
\hline T6 & $\begin{array}{c}\text { Carbendazim12 } \\
\%+\text { Mancozeb 63\% }\end{array}$ & SAAF & $1500 \mathrm{ppm}, 2000 \mathrm{ppm}$ \\
\hline T7 & Mancozeb & Indofil & $1500 \mathrm{ppm}, 2000 \mathrm{ppm}$ \\
\hline T8 & Copper oxychloride & Blitox & $1500 \mathrm{ppm}, 2000 \mathrm{ppm}$ \\
\hline
\end{tabular}

\section{Results}

Evaluation of systemic fungicides against Alternaria macrospora under in vitro conditions

Five systemic fungicides viz., Propiconazole, Hexaconazole, Tebuconazole, Pyraclostrobin and Azoxystrobin were tested in vitro against Alternaria spp. using poisoned food technique as described in material and methods. Isolate N2A was selected as the test pathogen since it was morphologically similar to A. macrospora and also showed maximum resemblance in molecular identification method. All five systemic fungicides evaluated in vitro were significantly found to influence mycelial growth and its corresponding inhibition of Alternaria spp. at concentrations each@ @ 500 and $1000 \mathrm{ppm}$ (Table.1, Figure.1 and Plate.1). Mycelial growth and its inhibition were found inversely and directly proportional, respectively to concentrations of the fungicides tested. Propiconazole, Hexaconazole and Tebuconazole @ 500 and 1000 ppm showed complete inhibition with no radial growth of mycelium whereas, the radial growth in Pyraclostrobin and Azoxystrobin @ 500 was $11.50 \mathrm{~mm}$ and $16.83 \mathrm{~mm}$ with 87.2 and 81.3 per cent inhibition respectively. Pyraclostrobin and Azoxystrobin @ 1000 ppm treatment recorded $8.0 \mathrm{~mm}$ and $11.50 \mathrm{~mm}$ radial growth respectively and its per cent inhibition was 91.0 and 87.2 per cent respectively.

Table 1: Evaluation of systemic fungicides against Alternaria macrospora under in vitro conditions

\begin{tabular}{|c|c|c|c|c|c|}
\hline \multirow{2}{*}{$\begin{array}{c}\text { Treatment } \\
\text { No. }\end{array}$} & \multirow{2}{*}{ Treatments } & \multicolumn{2}{|c|}{$\begin{array}{l}\text { Colony diameter } \\
(\mathbf{m m}) \text { at ppm }\end{array}$} & \multicolumn{2}{|c|}{$\begin{array}{c}\text { Per cent inhibition } \\
\text { at ppm }\end{array}$} \\
\hline & & 500 & 1000 & 500 & 1000 \\
\hline \multirow{2}{*}{1} & \multirow{2}{*}{ Propiconazole } & \multirow{2}{*}{00.00} & \multirow{2}{*}{00.00} & 100 & 100 \\
\hline & & & & $(90.00)$ & (90.00) \\
\hline \multirow{2}{*}{2} & \multirow{2}{*}{ Hexaconazole } & \multirow{2}{*}{00.00} & \multirow{2}{*}{00.00} & 100 & 100 \\
\hline & & & & $(90.00)$ & $(90.00)$ \\
\hline \multirow{2}{*}{3} & \multirow{2}{*}{ Azoxystrobin } & \multirow{2}{*}{16.83} & \multirow{2}{*}{11.50} & 81.3 & 87.2 \\
\hline & & & & (63.48) & (68.61) \\
\hline \multirow{2}{*}{4} & \multirow{2}{*}{ Tebuconazole } & \multirow{2}{*}{00.00} & \multirow{2}{*}{00.00} & 100 & 100 \\
\hline & & & & $(90.00)$ & $\begin{array}{l}(90.00) \\
\end{array}$ \\
\hline \multirow{7}{*}{5} & \multirow{2}{*}{ Pyraclostrobin } & \multirow{2}{*}{11.50} & \multirow{2}{*}{8.00} & 87.2 & 91.1 \\
\hline & & & & $(68.61)$ & $(72.56)$ \\
\hline & \multirow{2}{*}{ Control } & \multirow{2}{*}{90.00} & \multirow{2}{*}{90.00} & 00.00 & 00.00 \\
\hline & & & & $(00.00)$ & $(00.00)$ \\
\hline & C.D. & 0.752 & 0.583 & 0.512 & 0.412 \\
\hline & $\mathrm{SE}(\mathrm{m}) \pm$ & 0.236 & 0.183 & 0.227 & 0.129 \\
\hline & C.V. & 7.204 & 8.108 & 0.296 & 0.234 \\
\hline
\end{tabular}

*Average of three replications.

Figures in parentheses indicate angular transformed value.

Evaluation of non-systemic and combined fungicides agains Alternaria macrospora under in vitro conditions

Two non-systemic fungicides viz., Mancozeb and Copper oxychloride@ 1500 and 2000 ppm were evaluated under in vitro conditions using poisoned food technique as described in 3.8. The radial growth of Mancozeb and Copper oxychloride @ 1500 ppm observed was 14.50 and $12.50 \mathrm{~mm}$ respectively with per cent inhibition of 83.8 and 86.1 per cent respectively. While, the radial growth of Mancozeb and Copper oxychloride@ $@ 2000$ ppm observed was $12.5 \mathrm{~mm}$ and 6.46 $\mathrm{mm}$ respectively and showed 86.1 and 92.8 per cent inhibition respectively. Carbendazim+Mancozeb recorded the radial growth of $3.43 \mathrm{~mm}$ and

96.1 per cent inhibition at $1500 \mathrm{ppm}$ whereas, radial growth @ 2000 ppm was 2.76 with per cent inhibition of 96.9 per cent, which is significantly superior than non-systemic fungicide (Table. 2, Figure.2 and Plate.2)

Table 2: Evaluation of non-systemic and combi fungicides against Alternaria macrospora under in vitro conditions

\begin{tabular}{|c|c|c|c|c|c|}
\hline \multirow{2}{*}{$\begin{array}{c}\text { Treatment } \\
\text { No. }\end{array}$} & \multirow{2}{*}{ Treatments } & \multicolumn{4}{|c|}{ Colony diameter $(\mathrm{mm})$ at ppm Per cent inhibition at ppm } \\
\hline & & 1500 & 2000 & 1500 & 2000 \\
\hline \multirow{2}{*}{1} & \multirow{2}{*}{ Mancozeb } & \multirow{2}{*}{14.50} & \multirow{2}{*}{12.5} & 83.8 & 86.1 \\
\hline & & & & $(65.57)$ & $(67.95)$ \\
\hline \multirow{2}{*}{2} & \multirow{2}{*}{ Copper oxychloride } & \multirow{2}{*}{12.50} & \multirow{2}{*}{6.46} & 86.1 & 92.8 \\
\hline & & & & $(67.89)$ & $(73.26)$ \\
\hline \multirow{7}{*}{3} & Carbendazim $12 \%+$ Mancozeb & \multirow{2}{*}{3.43} & \multirow{2}{*}{2.76} & 96.1 & 96.9 \\
\hline & \begin{tabular}{|c|}
$63 \%$ \\
\end{tabular} & & & $(78.21)$ & $(79.61)$ \\
\hline & \multirow{2}{*}{ Control } & \multirow{2}{*}{90.00} & \multirow{2}{*}{90.00} & 00.00 & 00.00 \\
\hline & & & & $(00.00)$ & $(00.00)$ \\
\hline & C.D. & 0.958 & 1.214 & 0.650 & 0.986 \\
\hline & $\mathrm{SE}(\mathrm{m}) \pm$ & 0.271 & 0.344 & 0.184 & 0.279 \\
\hline & C.V. & 4.635 & 8.231 & 0.360 & 0.528 \\
\hline
\end{tabular}

*Average of three replications.

Figures in parentheses indicate angular transformed value 
The result of present studies are in agreement with the findings of viz., Arun Kumar (2008) ${ }^{[1]}$ who reported that out of nine different fungicides tested in vitro, Propiconazole, Hexaconazole at all the concentration $(0.1 \%, 0.2 \%$ and $0.3 \%)$ completely inhibited the mycelial growth of A. alternata infecting cotton.

Thaware et al. (2010) ${ }^{[11]}$ evaluated different fungicides under in vitro conditions against leaf blight of cotton caused by $\mathrm{A}$. alternata and showed that Mancozeb@0.2 per cent and Propiconazole@ 0.05 per cent completely inhibited the mycelial growth of test fungus.

Berman et al. (2015) ${ }^{[3]}$ estimated different fungicides against leaf blight of tomato caused by A. alternata@ 0.2 per cent concentration. They concluded that Bavistin showed 100 per cent inhibition followed by Captaf (81.2\%), Nystatin (73\%).

Mohan et al. (2018) [6] evaluated eleven fungicides against leaf blight of cotton caused by A. macrospora under in vitro conditions. Among all the tested fungicides mancozeb, carbendazim, hexaconazole, propiconazole and carbendazim + mancozeb showed complete inhibition $(100 \%)$ at all the tested dosages followed by captan + hexaconazole $(89.74 \%)$, thiram and captan $(78.89 \%)$ and azoxystrobin showed least inhibition $(56.81 \%)$ compared to untreated control.

Raut et al. (2019) ${ }^{[9]}$ evaluated seven non systemic fungicides viz., Chlorothaonil 75WP, Propineb 70WP, Mancozeb 75WP,
Copper oxychloride 50WP, Captan 50WP, Thiram 75WP and Ziram 27EC each @ 1500 and 2000 ppm concentration against A. macrospora which causes leaf blight of cotton. Among eleven fungicides maximum per cent inhibition was observed with Mancozeb $(86.95 \%)$, followed by Thiram (84.68\%), Ziram (81.76\%), Propineb $(80.23 \%)$ and Copper oxychloride $(75.57 \%)$, whereas, it was comparatively minimum with Chlorothaonil (55.29\%) and Captan (73.10\%).

\section{Discussions}

Evaluation of systemic, non-systemic and combined fungicides against Alternaria macrospora (N2A isolate) under in vitro conditions revealed that Propiconazole, Hexaconazole and Tebuconazole showed maximum inhibition (100\%)@ 500 and $1000 \mathrm{ppm}$ and no radial growth of mycelium was observed. Pyraclostrobin and Azoxystrobin at $500 \mathrm{ppm}$ recorded 87.2 and 81.3 per cent inhibition respectively, whereas@1000 ppm it was 91.0 and 87.2 per cent inhibition respectively. Mancozeb and Copper oxychloride@1500 ppm recorded 83.8 and 86.1 per cent inhibition respectively and it was 86.1 and 92.8 per cent at 2000 ppm respectively. Combined fungicide Carbendazim+Mancozeb (SAAF) @ $1500 \mathrm{ppm}$ and $2000 \mathrm{ppm}$ inhibited to the extent of 96.1 per cent and 96.9 per cent respectively.

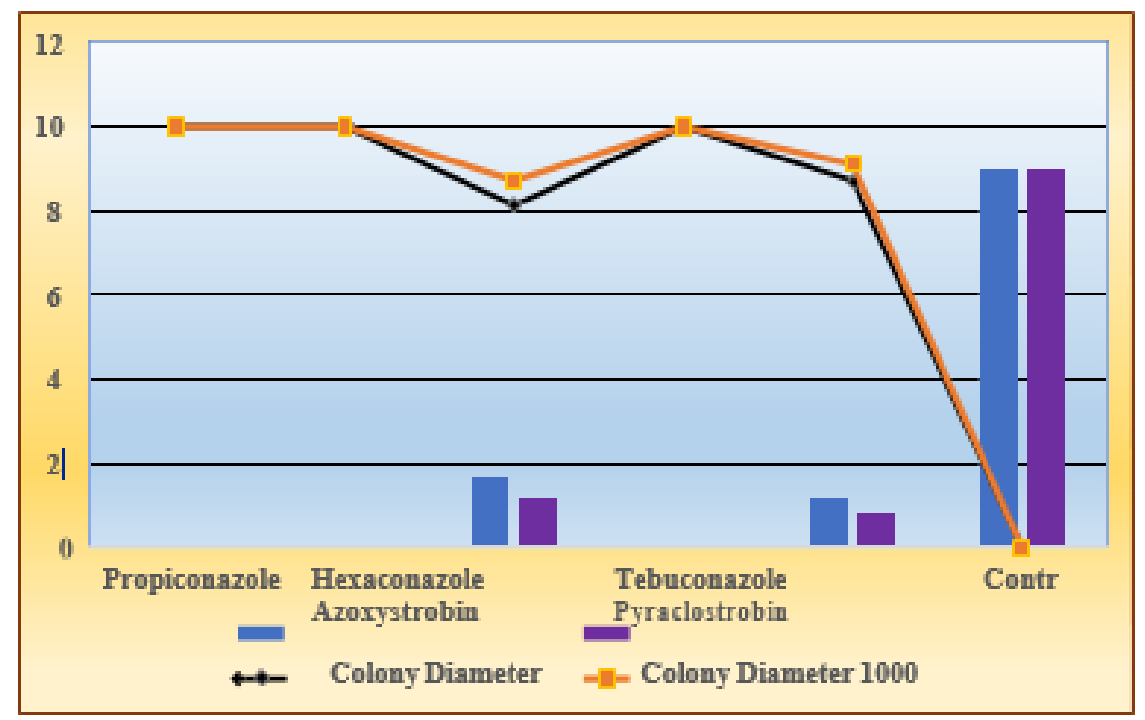

Fig 1: Efficacy of systemic fungicides against A. macrospora under in vitro conditions

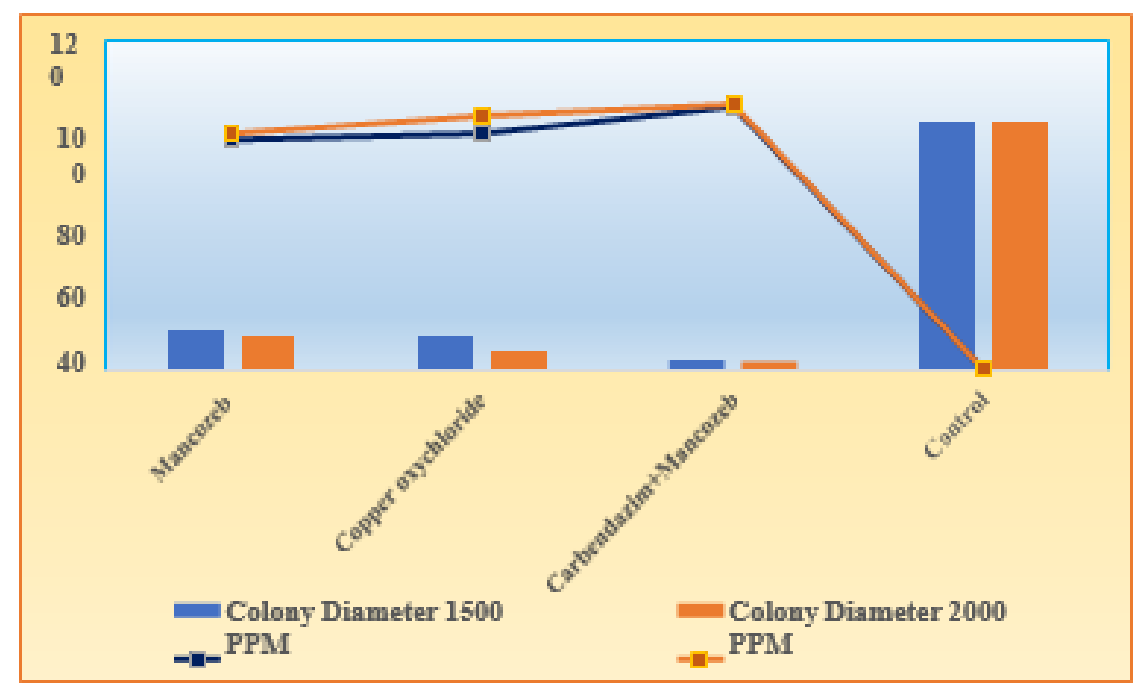

Fig 2: Efficacy of non-systemic and combined fungicides against A. macrospora under in vitro conditions 


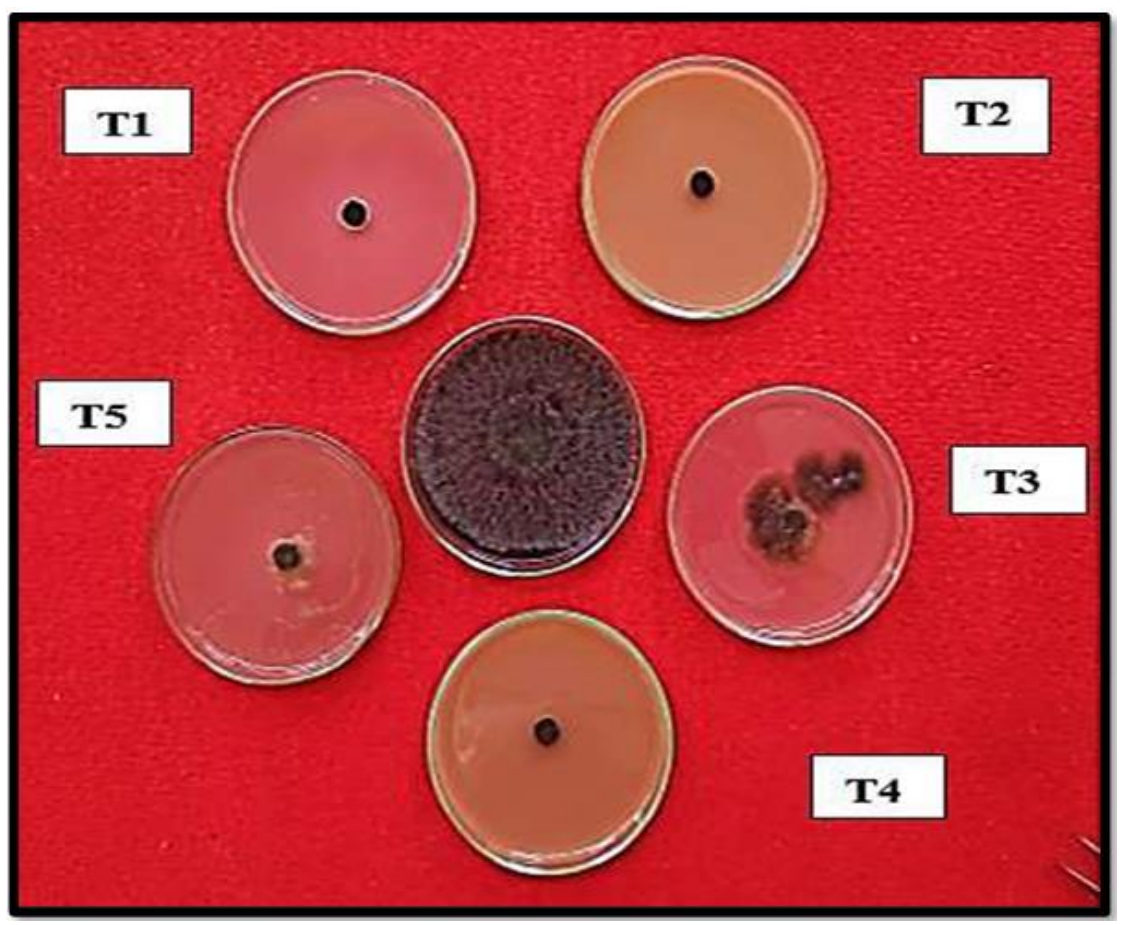

Plate 1(a): Efficacy of systemic fungicides at $500 \mathrm{ppm}$ on radial mycelial growth and inhibition of Alternaria macrospora under in vitro conditions

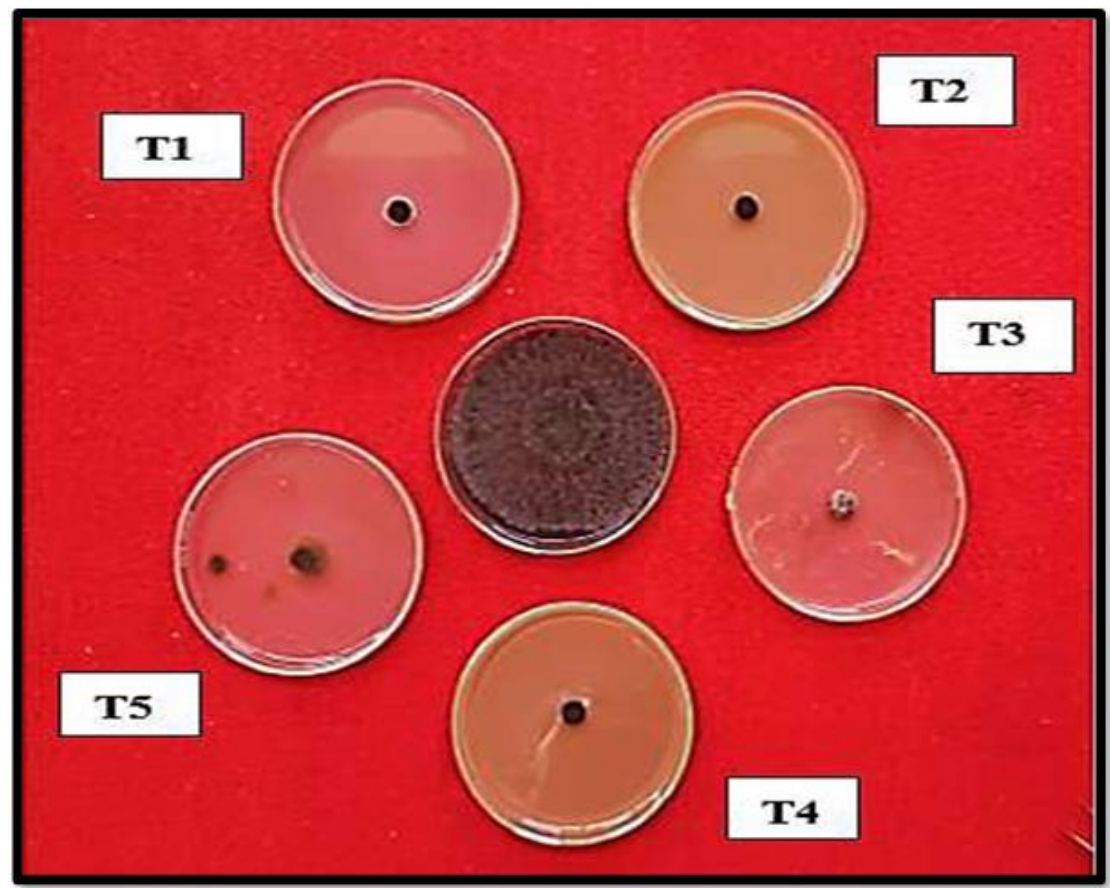

Plate 2(b): Efficacy of systemic fungicides at $1000 \mathrm{ppm}$ on radial mycelial growth and inhibition of Alternaria macrospora under in vitro conditions

\section{References}

1. Arun Kumar GS. Studies on leaf blight of chrysanthemum caused by Alternaria alternata (Fr.) Keissler. M. Sc. (Agri.) Thesis, University of Agricultural Science., Dharwad, Karnataka (India). 2008, 85 .

2. Bedane Gudeta, Arkebe Egziabher G. Cotton production potential areas, production trends, research status, gaps and future directions of cotton improvement in Ethiopia. Greener Journal of Agricultural Sciences. 2019; 9:163170 .

3. Berman H, Roy A, Das SK. Evaluation of plant products and antagonistic microbes against leaf blight (Alternaria alternata), a devastating pathogen of tomato. Trends Bioscience. 2015; 85(13):1908-1913.

4. Chitte Karishma, Taley SM, Atal GR, Paslawar AN, Katkar RN. Impact of tillage practices on crop growth and production in cotton under rainfed condition. Journal of Pharmacognosy and Phytochemistry. 2019; 8(4):858861.

5. Cotton Association of India. 2018-2019. Cotton Statistics and News. 41(4):3-8.

6. Mohan VSPB, Bhattiprolu SL, Prasanna KV, Anil Kumar $\mathrm{P}$. In vitro evaluation of fungicides against Alternaria macrospora causing leaf spot in cotton. International 
Journal of Current Microbiology and Applied Sciences. 2018; 7(1):2551-2557.

7. Nene YL, Thapliyal BW. Fungicides in Plant Disease Control. Oxford \& IBH Publisher house New Delhi. 1979, 425.

8. Prasad B, Bhattiprolu SL, Prasanna Kumari V, Anil Kumar P. In vitro evaluation of fungicides against Alternaria macrospora causing leaf spot in cotton. International Journal of Current Microbiology and Applied Sciences. 2018; 7(1):2551-2557.

9. Raut LS, Hamde VS. Screening of antifungal potential of rhizospheric isolates against Alternaria leaf blight disease of $B t$ cotton in vitro. International Journal of Current Microbiology and Applied Science. 2019; 5(8):769-784.

10. Sangameshwari P, Kumarimanimuthu Veeral D, Ganapathy M. Analysis of growing degree days for cotton. International Journal of Recent Scientific Research. 2019; 10:31548-31550.

11. Thaware DS, Fugro PA, Jadhav YT, Magar SV, Karande RA. In vitro evaluation of different fiungicides, plant extract and bio-agents against Alternaria alternata (Fr.) Keissler causing leaf blight of cowpea. International Journal of Plant Pathology. 2010; 3(2):356-360. 